\title{
A 2020 review on the role of procalcitonin in different clinical settings: an update conducted with the tools of the Evidence Based Laboratory Medicine
}

\author{
Anna Maria Azzini ${ }^{1}$, Romolo Marco Dorizzi ${ }^{2}$, Piersandro Sette ${ }^{3}$, Marta Vecchi ${ }^{1}$, Ilaria Coledan ${ }^{1}$, \\ Elda Righi ${ }^{1}$, Evelina Tacconelli ${ }^{1,4}$
}

${ }^{1}$ Section of Infectious Disease, Department of Diagnostics and Public Health, University of Verona, Verona, Italy; ${ }^{2}$ Clinical Pathology Unit, Department of Pathology, Transfusion and Laboratory Medicine, Ravenna, Italy; ${ }^{3}$ Hospital Management and Organization Department, Hospital of San Bonifacio, San Bonifacio, VR, Italy; ${ }^{4}$ Division of Infectious Diseases, Department of Internal Medicine I, University Hospital Tubingen, Tubingen, Germany

Contributions: (I) Conception and design: AM Azzini, RM Dorizzi; (II) Administrative support: None; (III) Provision of study materials or patients: All authors; (IV) Collection and assembly of data: All authors; (V) Data analysis and interpretation: RM Dorizzi; (VI) Manuscript writing: All authors; (VII) Final approval of manuscript: All authors.

Correspondence to: Anna Maria Azzini. Section of Infectious Disease, Department of Diagnostics and Public Health, University of Verona, Verona, Italy. Email: annamaria.azzini@univr.it.

\begin{abstract}
Biomarkers to guide antibiotic treatment decisions have been proposed as an effective way to enhancing a more appropriate use of antibiotics. As a biomarker, procalcitonin (PCT) has been found to have good specificity to distinguish bacterial from non-bacterial inflammations. Decisions regarding antibiotic use in an individual patient are complex and should be based on the pre-test probability for bacterial infection, the severity of presentation and the results of PCT serum concentration. In the context of a high pre-test probability for bacterial infections and/or a high-risk patient with sepsis, monitoring of PCT over time helps to track the resolution of infection and decisions regarding early stop of antibiotic treatment. As outlined by the Evidence Based Laboratory Medicine (EBLM), not only the pre-test probability but also the positive likelihood ratio influence the performance of a test do be really diagnostic. This aspect should be taken into account in the interpretation of the results of clinical trials evaluating the performance of PCT in guiding antibiotic therapy.
\end{abstract}

Keywords: Procalcitonin (PCT); Evidence Based Laboratory Medicine (EBLM); antibiotic therapy

Submitted Feb 24, 2020. Accepted for publication Apr 17, 2020.

doi: $10.21037 / \mathrm{atm}-20-1855$

View this article at: http://dx.doi.org/10.21037/atm-20-1855

In the bid towards a more appropriate use of antibiotics, biomarkers have been found to be an effective support to clinicians in their antibiotic treatment decisions. As a biomarker, procalcitonin (PCT) is valued for its specificity in differentiating between bacterial and nonbacterial inflammation and is considered of utility to avoid unnecessary antibiotic prescriptions as well as to reduce the duration of antibiotic therapy (1). The aim of this paper is to review PCT use in different clinical settings and patient populations with a focus on trials and meta-analysis published between 2010 and 2019, in order to consider reagents and analyzers that are still used in laboratories and interpreting the collected data with the Evidence Laboratory Medicine tools (2-4).

\section{PCT in infected critically ill patient}

The use and usefulness of PCT as a biomarker is covered extensively in literature in two main areas: as an early marker of sepsis (differentiating bacterial and non bacterial etiologies) and as a guide to the management of antibiotic therapy (5-20). In recent decades, there has been a shift 
in the focus on PCT as a biomarker able to guide the discontinuation of antibiotic therapy, particularly in critically ill patients $(5,7,9,10,12-16,18)$, demonstrating its safety and efficacy either alone or in association with other biomarkers, such as C-reactive protein (CRP), alpha 2 macroglobulin (A2M) and presepsin $(19,21,22)$.

PCT has been compared with CRP to guide antibiotic therapy in septic patients, resulting equally effective in reducing antibiotic use (22). A recent review provided evidence that the diagnostic accuracy of PCT and presepsin to detect infections in critically ill adults was similar, without significant differences both in pooled sensitivity $(\mathrm{P}=0.48)$ and specificity $(\mathrm{P}=0.57)(5)$. The combination of $\mathrm{A} 2 \mathrm{M}$ and PCT (collected at baseline and after 72 hours) achieved a negative predictive value (NPV) of $75 \%$ (95\% CI, 54-96\%) and was able to discriminate between bacterial sepsis and other causes of systemic inflammatory response syndrome (SIRS) in patients with suspected post-surgical sepsis (21). Conversely, in other trials the real efficacy provided by PCT in guiding the clinician's diagnosis has been questioned $(7,8,10,11,19,23)$. Jeon et al. (9) confirmed the role of PCT as a biomarker capable of reducing the duration of antibiotic treatment, but found that its use did not impact on clinical cure, 28-day mortality, in-hospital mortality, ICU length of stay and overall hospital length of stay, when comparing the PCT-guided and the control group of patients. Pepper et al. evaluated the PCT-guided antibiotic discontinuation approach in a systematic review including 16 randomized clinical trials (RCTs) (23); they found that this approach was associated with decreased mortality (risk ratio, 0.89; 95\% CI, 0.83-0.97) and with a decrease in antibiotics' duration (mean difference, 1.31 days; $95 \%$ CI, -2.27 to -0.35). They also found low-certainty evidence to support this PCT's clinical use, concluding that it was difficult to attribute the survival benefit to a PCT-guided approach as the reported examples were from studies where the protocol was not always strictly observed (i.e., investigators frequently overruled PCT guidance) or in which PCT were associated with other biomarkers (CRP) (23).

Two recent papers investigated the cost-effectiveness of PCT-guided antibiotic discontinuation in The Netherlands, a country that has a tradition of a low rate of antibiotic prescription both in the hospital setting and in the community $(24,25)$. Kip et al. showed that a PCTbased algorithm for antibiotic discontinuation in ICU adult patients is safe and offers a cost-effective means of reducing antibiotic exposure (24). The same authors compared cost- effectiveness of PCT testing and no-PCT testing in guiding antibiotic treatment duration in critically ill patients (25). Despite a mean lower course duration of antibiotics in the PCT-guided group, healthcare costs over a one-year time target were $€ 73,665$ /patient compared with $€ 70,961 /$ patient in the standard of care group, with a modest impact of PCT's use on total healthcare-related costs (25). They concluded that the long-term cost-effectiveness of PCT guidance needs more studies, also in countries characterized by different antibiotic consumption if compared to The Netherlands (25).

\section{PCT in lower respiratory tract infections}

Pneumonia and acute respiratory infections (ARI) are a major cause of morbidity and mortality and ARI encompasses heterogeneous group of both bacterial and viral infections. Prompt intervention in terms of antibiotic treatment is crucial for the effective treatment of bacterial ARIs and is considered key to improve clinical outcomes; however, the etiologic diagnosis is not always achieved. Furthermore the overuse of antibiotics for acute respiratory syndrome [outpatients with bronchitis, prolonged antibiotic therapy in people with bacterial ARIs in hospital and intensive care unit (ICU)] is associated with the increase of multi-drug resistant bacteria, higher costs and adverse drug reactions (26).

PCT appears to be particularly sensitive to bacterial toxins compared to other biomarkers such as white blood cells (WBC) and CRP, and it undergoes down-regulation in the presence of viral infections. In 2017 PCT was approved as a marker to guide antibiotic therapy in lower respiratory tract infections, by the US Food and Drug Administration but, despite this step, there is no consensus about the usefulness of this marker to guide antimicrobial therapy in the currently available international guidelines for the management of pneumonia. The role of PCT in ARI has been studied in RCTs considering different settings (ICU; outpatients), to address when antibiotics should be initiated and when they should be interrupted. Many studies evaluated the use of PCT as part of a flow-chart, but one of the main obstacles they met was the definition of a standardized and accepted cut-off level. Most studies agreed to begin the antimicrobial therapy as follows: PCT $<0.1 \mathrm{ng} / \mathrm{mL}$ strongly discouraged, PCT $<0.25 \mathrm{ng} / \mathrm{mL}$ discouraged, PCT $>0.25 \mathrm{ng} / \mathrm{mL}$ encouraged, PCT $>0.5 \mathrm{ng} / \mathrm{mL}$ strongly recommended (12).

Some recent RCTs investigated if the use of PCT might be associated with improved antibiotics prescription. 
Huang et al. (27) involved 1,656 patients with suspected lower respiratory tract infection and found that antibiotic treatment decisions based on PCTs did not lead to a reduction in the use of antibiotics when compared with standard care. The authors reported that while in some cases they discontinued antibiotics on the basis of PCT levels, they also used this biomarker to prescribe antibiotics in the PCT-guided group. Christ-Crain et al. (28) conducted a study involving patients affected by suspected community-acquired pneumonia (CAP) presenting to the emergency department. The therapy was oriented by a PCT-based algorithm in 151 patients, whereas other 151 received standard approach. In the case of the first group, the result was a reduction of antibiotic prescription (both total antibiotic exposure and duration: 5 versus 12 days). Briel et al. (29) conducted a multicenter RCT in primary care involving 458 patients who required antibiotics: these patients were randomized to either PCT-guided therapy (antibiotics strongly discouraged if PCT $\leq 0.1 \mathrm{ng} / \mathrm{mL}$ or encouraged if $>0.25 \mathrm{ng} / \mathrm{mL}$ ) or a standard approach. In the PCT-group, the overall antibiotic prescription rate was $72 \%$ lower and the treatment's duration was also found to be 1 day shorter; adverse events were the same for both groups. Akagi et al. (30) found that using a PCTguided antibiotic discontinuation algorithm, the duration of antibiotic treatment is shortened by 3 days without any impact on pneumonia recurrence or 30-day mortality.

Schuetz et al. (26) conducted a systematic review to assess the safety and efficacy of PCT to start or interrupt antibiotics over a large range of patients with varying severity of ARIs and from different clinical settings. The results showed a significantly lower mortality associated with PCT-guided therapy, with a shortening of antibiotic treatment of 2.4 days and lower risk of antibiotic-related side effects. The systematic review and meta-analysis by Kamat et al. (31) suggest that PCT is unlikely to provide information that will enable clinicians to immediately address whether a CAP is bacterial, and antibiotics need to be administered, or whether it is viral, and antibiotics may be withheld. The sensitivity (overall 55\%) and specificity $(76 \%)$ were both too low and variable for the results to be confidently used in the decision-making process. The calculated LR+, LR- and DOR are respectively 2.3, 0.4 and 3.9 , resulting inadequate for an effective diagnostic test. Finally, in a recently published review made by Creamer et al. (32), the authors' conclusion was that there are no recommendations for using PCT in managing $\mathrm{CAP}$ and that there is only one circumstance where PCT-guided therapy is validated by international guidelines, namely in complex hospital-acquired or ventilator-associated pneumonia.

\section{PCT in chronic obstructive pulmonary disease (COPD)}

COPD is one of the most important causes of morbidity and mortality worldwide (33) and acute COPD exacerbations (AECOPD) represent a major health concern because of the progressive worsening of clinical condition (34). Clear criteria do not exist to distinguish an AECOPD from a daily respiratory variation. Furthermore, there is a lack of understanding regarding the AECOPD's pathogenesis: infective causes would be involved in 50\% cases (35). Therefore, for an adequate management of AECOPD, antibiotics could be necessary but it is difficult to discriminate infectious from non-infectious episodes and antibiotic overuse can promote the onset of resistance and increase adverse reactions (27). Global Initiative for Obstructive Lung Disease (GOLD) recommendations suggest antibiotics when the patient presents at least two of the three cardinal symptoms (dyspnea, increased sputum production and purulence) or in presence of severe respiratory impairment (36).

Over the years, many researchers have attempted to identify a biomarker that goes beyond the clinical presentation and that would allow physicians to act more confidently. Compared to WBC and CRP, PCT has proven to be a more specific parameter of infections (32), and some authors have studied a PCT-guided algorithm as a useful tool to lead physicians to smart antibiotic therapies in patients affected by COPD. Generally speaking, all the cited studies $(27,32-45)$ have tried to address the same questions: can PCT orient medical decisions? Can a PCTguided algorithm show when antibiotics are necessary and when they are not, thus maintaining efficacy and safety? Can this strategy be also cost-effective? Despite the efforts, there is still insufficient evidence to draw solid conclusions. Firstly, there is no agreement about the real usefulness of PCT. According to Ni et al. (37), PCT has a moderate ability to identify bacterial respiratory infections in AECOPD, but does not have a strong diagnostic value in patients admitted in ICU. Lin et al. (34) concluded that PCT-guided treatment reduces the abuse of antibiotics, but Verduri et al. (38) were not able to demonstrate the non-inferiority of PCT-guided antibiotic treatment compared to standard treatment and Daubin et al. (35) came to the same conclusion. Moreover, even if PCT can 
be useful together with symptoms and other biomarkers, a universal cut-off has yet to be defined. In Mathioudakis et al. (39) some studies used a cut-off $\geq 0.25 \mathrm{ng} / \mathrm{mL}$ to recommend antibiotics; Li et al. (40) considered values between 0.1 and $0.25 \mathrm{ng} / \mathrm{mL}$ and van der Maas et al. (41) values greater than $0.5 \mathrm{ng} / \mathrm{mL}$ to orient medical decisions. Furthermore many studies are flawed because of the low adherence to the protocols $(32,42)$; according to van der Maas et al. (41), a PCT-guided algorithm seems to be more cost-effective than the current practice.

\section{PCT in acute infections of central nervous system}

Acute meningitis is classified into bacterial meningitis (BM) and nonbacterial meningitis. It can be extremely challenging to diagnose patients with BM, particularly because the clinical distinction between viral meningitis $(\mathrm{VM})$ and $\mathrm{BM}$ is complex especially in the acute phase. The positivity of cerebrospinal fluid (CSF) culture, or Gram staining or the detection of bacterial antigens in the CSF, constitute the gold standard in BM diagnosis. They have high specificity but sensitivity is poor. Furthermore, bacterial culture is time-consuming. Therefore, in some cases, antibiotics are administered while waiting for CSF results or until a diagnosis of VM can be confirmed (46).

Biomarkers such as CRP and WBC help in distinguishing between $\mathrm{BM}$ and VM; however, neither of these tests achieve 100\% sensitivity (47-49). CRP, traditionally a biomarker for inflammation, may show a delayed increase during a bacterial infection, resulting in false-negative results in the early stages of the disease (50-52). CRP can also be elevated in viral infections, limiting its ability to discriminate between bacterial and viral etiologies (53), and more sensitive and specific markers for BM are desirable (54).

In an observational study by Alkholi et al. (55), patients with BM were found to have increased serum PCT compared with the control group $(\mathrm{P}<0.001)$ at the time of diagnosis. Similarly, when comparing patients with $\mathrm{BM}$ and VM, the first was found to have increased serum PCT at the time of diagnosis (PCT, $\mathrm{P}<0.001)$. PCT level in VM cases is not so high which means that it is more accurate than CRP as a marker of systemic bacterial infection (56-58).

In terms of diagnostic cut-off levels, optimum sensitivity and specificity were calculated to be PCT $>10 \mathrm{ng} / \mathrm{mL}$; a PCT $>2 \mathrm{ng} / \mathrm{mL}$ had $100 \%$ sensitivity and high NPV for BM, but with a specificity of only $60 \%$ and positive predictive value of $68 \%$. Follow-up of cases showed a significant reduction in PCT levels on the third day after antibiotic treatment initiation. This result is documented in many studies $(59,60)$ and as such PCT can be considered a parameter for evaluating the efficacy of antibiotic treatment.

In 2015 a meta-analysis (61) including nine studies (62-70) demonstrated that serum PCT was a highly accurate test for diagnosing meningitis. The pooled sensitivity, specificity, LR+, LR-, and DOR for PCT were 0.90 (95\% CI, 0.84-0.94), 0.98 (95\% CI, 0.97-0.99), 27.3 (95\% CI, 8.2-91.1), 0.13 (95\% CI, 0.07-0.26), and 287.0 (95\% CI, 58.5-1,409.0), respectively. PCT was found to be far superior to CRP, which had a pooled DOR of only 22.1 (95\% CI, 12.7-38.3). For PCT the area under the curve (AUC) was 0.97 (standard error $=0.03$ ). This analysis demonstrated that serum PCT was a highly accurate diagnostic test for distinguishing between bacterial and viral or non-infective etiologies in patients with suspected meningitis.

Furthermore, PCT was found to be more specific than sensitive. For this reason, the authors concluded that it would be opportune to use it in association to the traditional approach which considers the clinical history, physical examination, laboratory tests, and CSF analysis. This, with a view to increasing the overall diagnostic accuracy in differentiating the etiology of suspected meningitis. Considering its high sensitivity and specificity, PCT would be of added value in cases where conventional tests are unable to reach a conclusive diagnosis (i.e., non-conclusive CSF findings).

Another meta-analysis by Wei et al. (54) included twentytwo studies to ascertain the diagnostic accuracy of blood and CSF-PCT as a marker for BM detection (49,55,56,6265,68-82): overall, the diagnostic sensitivity of CSF-PCT detection was 0.80 (95\% CI, 0.61-0.91), specificity was 0.86 (95\% CI, 0.70-0.95), LR+ was 5.9 (95\% CI, 2.4-14.0), LRwas 0.23 (95\% CI, 0.12-0.47), and DOR was 25 (95\% CI, 8-78). The diagnostic sensitivity of blood PCT detection was 0.95 (95\% CI, 0.89-0.97), specificity was 0.97 (95\% CI, 0.89-0.99), LR+ was 31.7 (95\% CI, 8.0-124.8), LRwas 0.06 (95\% CI, 0.03-0.11), DOR was 568 (95\% CI, 103-3,141). The AUCs for CSF-PCT and blood PCT were 0.90 (95\% CI, 0.87-0.92) and 0.98 (95\% CI, 0.97-0.99), respectively. The $95 \%$ CIs for the AUCs of CSF-PCT and blood PCT did not overlap, indicating that the overall diagnostic accuracy of blood PCT detection was superior to CSF-PCT. In particular, their results indicated that positive blood PCT could confirm a diagnosis of BM, while negative 
blood PCT alone is sufficient to rule out it.

More recently, a cross-sectional study evaluated lactate, PCT, ferritin, CRP, and other known biomarkers in differentiating BM from VM and it found really opposite results because concentrations of all markers were significantly different in the two groups, except for blood and CSF-PCT. The mean CSF-PCT levels in patients with bacterial and viral/aseptic meningitis were 0.6 and $0.5 \mathrm{ng} / \mathrm{mL}$, respectively $(\mathrm{P}=0.136)$; the mean serum PCT levels were 0.7 and $0.6 \mathrm{ng} / \mathrm{mL}$ in bacterial and viral/ aseptic groups respectively $(\mathrm{P}=0.389)$. Using a cut-off of $0.4 \mathrm{ng} / \mathrm{mL}$, CSF-PCT had poor sensitivity (75\%), specificity (47\%), LR+ (1.4), LR- (0.7) and DOR (2.7); using a cut-off of $0.6 \mathrm{ng} / \mathrm{mL}$, serum PCT had sensitivity of $66.7 \%$ a specificity of $59.3 \%$, with $1.6 \mathrm{LR}+, 0.6 \mathrm{LR}$ - and 2.9 DOR (83). They concluded that both CSF and serum PCT were weak marker in differentiating BM and VM.

\section{PCT in infectious complications of polytrauma}

Trauma is the principal cause of death in adulthood $(>40$ years of age) and the third leading cause of death overall $(84,85)$. The management of patients with polytrauma can be complex and the clinical course can be fraught with complications, leading ultimately to mortality (86); death can occur immediately after injury ( $45 \%$ of cases), within the first day (10\%) (brain injury or uncontrolled haemorrhage) and in the following days $(45 \%)$ as a result of major complications [sepsis, respiratory distress syndrome and multiple organ failure syndrome (MOF)] (87). Sepsis is the main cause of late death ( $>1$ week) because of an up regulation of anti-inflammatory agents and consequent anergy that can precipitate patients in septic MOF (87-92).

Early diagnosis and treatment of infection is associated with improved outcome and reduced mortality (93), but the diagnosis of septic complications in major trauma is challenging as trauma per se provokes a strong SIRS that can mask clinical symptoms associated with sepsis (88-92). Bacterial culture is the standard in diagnosing the pathogen during sepsis (94) but immediate positive bacterial culture results are often unavailable and new rapid-diagnosis techniques are not always available in routine clinical practice (95).

Recently, two meta-analyses considered biomarkers predicting sepsis in polytrauma patients $(96,97)$. Ciriello et al. (96) showed that PCT has rapid kinetics, with levels peaking at $24-48 \mathrm{~h}$ after trauma and rapid decrease in non- complicated patients (98-102). Persistent high levels or secondary increases were adequate predictors of sepsis (98101,103-106), and MOF (100,103,106-108). The authors found PCT to be useful in predicting septic course and in allowing early diagnosis of MOF and of significant infective complication. However, by the same token, the authors pointed out that sensitivity and specificity reported for PCT at the different cut-off levels meant that it could not be used as a single indicator of sepsis and that the trend of PCT, as opposed to a single value, was the best tool to indicate infective complications.

AlRawahi et al. (97) identified 19 studies (4,146 patients), many of them in common with Ciriello. Most studies showed rapid kinetics of PCT levels with peak levels reached 1 day after trauma (98-106,108-112), and to a lesser extent on day $2(113,114)$. Two studies demonstrated that a biphasic rise in PCT after one week was associated with development of sepsis $(98,114)$. Nine studies $(47.4 \%)$ $(99,100,102,106-110,112)$ investigated the correlation between initial PCT level and the severity of trauma using injury severity score (ISS) (115): at the beginning PCT was higher in case of severe trauma (ISS >20) $(99,102,106,110)$. Sixteen studies (84.2\%) assessed the value of PCT level as a marker for sepsis $(98-109,111,114,116,117)$. After reaching the peak level on day 1 after trauma, PCT declined immediately towards reference interval $(98,102-104,106)$. However, the peak was significantly higher in patients who subsequently developed sepsis compared to those without sepsis $(98,100,102-107,109,110)$. Furthermore, patients who developed sepsis demonstrated a significant increase of peak PCT levels compared with patients with non-infectious SIRS $(98,99,101,106)$. Furthermore seven studies demonstrated significantly higher initial PCT levels in patients who subsequently developed multi organ dysfuncion (MOD) compared to those without MOD $(100,101,105,106,108,112,114)$.

\section{PCT in infectious complications of burns}

Severe burn injuries are a major insult: tissue injury, with the release of multiple local and systemic mediators of inflammation, determines an increased vascular permeability resulting in significant hydro-electrolytic and cardiovascular alterations (118), rapidly evolving to shock. In the past, shock was the primary cause of death in burn patients. However, thanks to advances in intensive care, this is no longer the case (119). Today, sepsis is the leading cause of death in this type of patient, occurring 
generally in a late post-traumatic period $(119,120)$. Early diagnosis of sepsis is crucial for the management and outcome of critically burned patients. Nevertheless signs of infection may be obscured by systemic dysfunction. All burns $>15-20 \%$ of total body area surface (TBSA) have a SIRS that persists for months after the wound is closed, so that at baseline burn patients always have the signs used to diagnose sepsis in the general population (121). To improve clinical criteria for sepsis detection in burned patients, members of the American Burn Association suggested the modification of some cut-offs of the SIRS parameters and the concomitant documentation of infection (122). Notwithstanding the above, it can still take quite a few days before microbiological agents can be identified conclusively (123).

PCT has been proposed as a biomarker to early identify a septic process and to select burned patients for prompt antibiotic therapy. Moreover, when PCT levels are under the cut-off values defined for septic processes, it may suggest antibiotic discontinuation, also becoming useful to avoid unnecessary therapy. In a systematic review by Mann et al. (124), two meta-analyses resulted in differing conclusions. The diagnostic odds ratio (OR) of PCT to diagnose sepsis reported by Jones et al. (125) was 9.86 (95\% CI, 5.72-17.02), in contrast with Tang et al. (126) for which an OR of 7.79 (95\% CI, 5.86-10.35) was calculated for the ability of this test to accurately discriminate between sepsis and non-septic SIRS. Mann et al. concluded that utility of the PCT assay is limited due to the lack of availability of rapid, inexpensive tests. In the same systematic review, six clinical trials conducted on burn injured patients were also retrieved (127-132). In burn specific studies, varying cut-off levels of PCT were observed, namely: from $0.5 \mathrm{ng} / \mathrm{mL}$ (sensitivity $100 \%$ and specificity $89.8 \%$ for diagnosis of sepsis) (127) and $0.53 \mathrm{ng} / \mathrm{mL}$ (sensitivity $42.4 \%$ and $88.8 \%$ ) (128) to $3.0 \mathrm{ng} / \mathrm{mL}$ associated with septic complications (130). Sachse et al. (132) reported a $1.5 \mathrm{ng} / \mathrm{mL}$ rise in daily PCT levels simultaneously with a septic event. There was no improvement in detection of sepsis using PCT compared with CRP in a study of pediatric burn patients (131). Lavrentieva et al. (129) found the PCT cut-off level of $1.5 \mathrm{ng} / \mathrm{mL}$ to have the highest sensitivity (82\%) and specificity (91.2\%) in septic patients (7.7 LR+ and 0.13 LR-), and found a sensitivity of $88 \%$ and specificity $92.2 \%$ considering a PCT cut-off of $1.5 \mathrm{ng} / \mathrm{mL}$ in case of wound infection (11.5 LR+, $0.2 \mathrm{LR}-$ ); in burn patients with respiratory tract infection a PCT cut-off of $0.56 \mathrm{ng} / \mathrm{mL}$ showed respectively $75 \%$ sensitivity, $80 \%$ specificity, a LR+ of 4 and a LR- of 0.3 . von Heimburg et al. demonstrated an association between increasing TBSA and increasing PCT level (130). Neely et al. (131) did not identify any improvement using PCT to detect sepsis if compared with CRP. In a study by $\mathrm{Su}$ et al. (133) PCT and CRP were both increased in burn sepsis, but they were considered not to be reliable markers for the early diagnosis of this condition; $\mathrm{Zu}$ et al. made the same observation (134). Mokline et al. found that five days after burn injury, PCT serum concentration was significantly different $(\mathrm{P}=0.001)$ between infected and noninfected patients $(5.44 \pm 6.23$ and $0.41 \pm 0.64 \mathrm{ng} / \mathrm{mL})$; a PCT cut-off value of $0.69 \mathrm{ng} / \mathrm{mL}$ showed the optimal sensitivity (89\%), specificity (85\%), LR+ (5.9), LR- (0.2) and DOR (45.8) (135). They concluded that PCT levels correlate closely with sepsis severity, could have a prognostic value in the outcome and repeated measurements were more useful than single values (135).

More recently a meta-analysis by Cabral et al. yielded an overall AUC of 0.87 , a sensitivity of $77 \%$, and a specificity of $65 \%$. The mean PCT level was $46.8 \mathrm{ng} / \mathrm{mL}$ (95\% CI, $2.5-91.1)$ in patients with sepsis and $0.9 \mathrm{ng} / \mathrm{mL}(95 \%$ CI, 0.1-1.6) in those without sepsis. These results led the authors to propose that PCT $>1.5 \mathrm{ng} / \mathrm{mL}$ could be an indicator of sepsis and should, therefore, spur clinicians to commence antibiotic therapy (sensitivity $43 \%$, specificity $83 \%, \mathrm{LR}+2.5, \mathrm{LR}-0.4$ and DOR 3.8) (136).

Results on the utility of PCT levels to early detect sepsis in burned patients are controversial, probably the use of different combinations of different biomarkers could overcome their individual limitations $(137,138)$.

\section{PCT in infectious complications of pancreatitis}

Infection of pancreatic necrosis (IPN) represents an important complication in acute pancreatitis (AP) and the role of PCT in this condition remains controversial. Some studies, however, highlight its usefulness in anticipating the risk of developing IPN (139-142). In 2000, Rau et al. found that PCT concentrations were significantly higher in IPN than in patients with severe necrosis, whereas CRP levels did not differ in both groups. IPN could be predicted with a PCT concentration $\geq 1.8 \mathrm{ng} / \mathrm{mL}$ on at least two consecutive days, showing $95 \%$ sensitivity, $88 \%$ specificity, LR+ 7.9, LR- 0.1 , number needed to diagnose (NND) 139. A CRP cut-off value of $300 \mathrm{mg} / \mathrm{L}$ showed $86 \%$ sensitivity, $75 \%$ specificity, LR+ $3.4, \mathrm{LR}-0.3$ and NND 18.4 (142). 
In 2009 a systematic review assessed the value of PCT in predicting the severity of $\mathrm{AP}$ and the development of IPN. The pooled sensitivity of PCT for development of severe AP was $72 \%$, specificity $76 \%$, with a LR+ of 5.1 , a LR- of 0.2 , a DOR of 15.8 and NND 1.7. In the prediction of development of IPN pooled sensitivity was $80 \%$ and specificity 90\%, with $8.9 \mathrm{LR}+, 0.1 \mathrm{LR}-$, 40.4 DOR and 1.4 NND. The authors concluded that PCT was valuable in predicting the severity of $\mathrm{AP}$ and the risk of developing pancreatic necrosis (140).

Chen et al. explored if CRP and PCT, collected within early 48 hours of hospitalization, were independently related to the development of IPN during necrotizing pancreatitis (141). The cut-off value of CRP was $257.50 \mathrm{mg} / \mathrm{L}$ with a sensitivity of $44.8 \%$ and specificity of 89.1\%, LR+ 4.1, LR- 0.2, DOR 6.6 and NND 2.9. The cut-off value of PCT was $1.39 \mathrm{ng} / \mathrm{mL}$ with a sensitivity of $60.9 \%$ and specificity of $75.0 \%, L R+2.4, L R-0.4$, DOR 4.7 and NND 2.8 (141). They concluded that the maximum levels of PCT and CRP within 48 hours of admission were an independent factor for IPN. Furthermore, the combined diagnosis with CRP, PCT, hematocrit and blood urea nitrogen, could predict the occurrence of IPN secondary to NP within 48 hours after admission (141).

The 2019 World Society of Emergency Surgery (WISES) guidelines for the management of severe acute pancreatitis recognise serum PCT as valuable tool in predicting the risk of developing infected pancreatic necrosis. However, the grade and strength of recommendation was $1 \mathrm{~B}$ on the basis that the quality of evidence remained moderate due to RCTs with important limitations (143). The IAP/APA (International Association of Pancreatology/American Pancreatic Association) evidence-based guidelines, include PCT among the single serum markers (e.g., CRP, hematocrit, blood urea nitrogen) to predict AP, specifying that none of these are clearly superior or inferior to persistent systemic inflammatory response (144).

Iida et al. recently reviewed literature and their experience concerning serum PCT as a predictor of infectious complications after pancreaticoduodenectomy (PD) (145). In a study including 77 patients undergoing $\mathrm{PD}, \mathrm{PCT}$ was the most significant factor predicting infectious complications on post-operative day 3 (sensitivity $87 \%$; specificity $88 \%$ ) (145). Conversely, in a review including 6 studies examining the role of preoperative and postoperative PCT and CRP, all reports demonstrated the usefulness of PCT as a predictor of infectious complications in postoperative patients, but did not identify any advantage compared to CRP (145). They further noticed that the current cost of PCT in Japan was about 10 times that of CRP leading to the conclusion that this biomarker is less cost-effective than CRP for predicting infectious complications after PD (145).

Recently Komolafe et al. compared the diagnostic accuracy of CRP, PCT and LDH, either alone or in combination, in the diagnosis of $\mathrm{NP}$ in people with $\mathrm{AP}$ and without organ failure. The authors concluded that none of the tests were sufficiently accurate to suggest that they could be useful in clinical practice. In particular PCT at $0.5 \mathrm{ng} / \mathrm{mL}$ showed $75 \%$ sensitivity, $57 \%$ specificity, LR+ 1.7, LR- 0.6, DOR 4 and NND 3.1 (146).

\section{Conclusions}

Notwithstanding the fact that there are several RCT and observational trials assessing the usefulness of PCT in early diagnosis of septic events in different clinical settings (critically ill patients, burned and polytrauma patients), uncertainty remains with regard to its use in starting and stopping clinical decisions for antibiotics. Table 1 shows the weight of the evidence supporting the role of PCT in different clinical conditions.

Positive and negative likelihood ratios (LR+; LR-), express the capacity of a test to increase certainty about a positive/negative diagnosis; the diagnostic odds ratios (DOR) combines the strengths of sensitivity and specificity (168); the NND, indicates the number of tests to carry out in order to gain a positive response for the presence of a disease (169). Only 16 of the LRs+ cited in the references are greater than 5 and only 4 greater than 10. A LR equal to 1.0 is not helpful because it means that the PCT value is the same in the same number of sick and healthy subjects for the pathology considered. The greater than 1.0 the $\mathrm{LR}+$ is, the greater the increase of disease probability. LRs+ between $2-5$ produce small increases in post-test probability of disease, 5-10 moderate increases and over 10 large increases (170). As suggested by McGee et al. a LR of 2 increases the probability by $15 \%, 5$ by $30 \%$, and 10 by $45 \%(170,171)$. This means that with a pre-test probability of $30 \%$ and a $\mathrm{LR}+$ of 2 , when the test is positive, post-test probability is only $45 \%(30 \%+15 \%)$.

In conclusion, definitive answers remain elusive owing to the heterogeneity of results obtained in different clinical setting, both in terms of diagnostic accuracy of PCT and in terms of its usefulness in guiding the discontinuation of antibiotic therapy. 


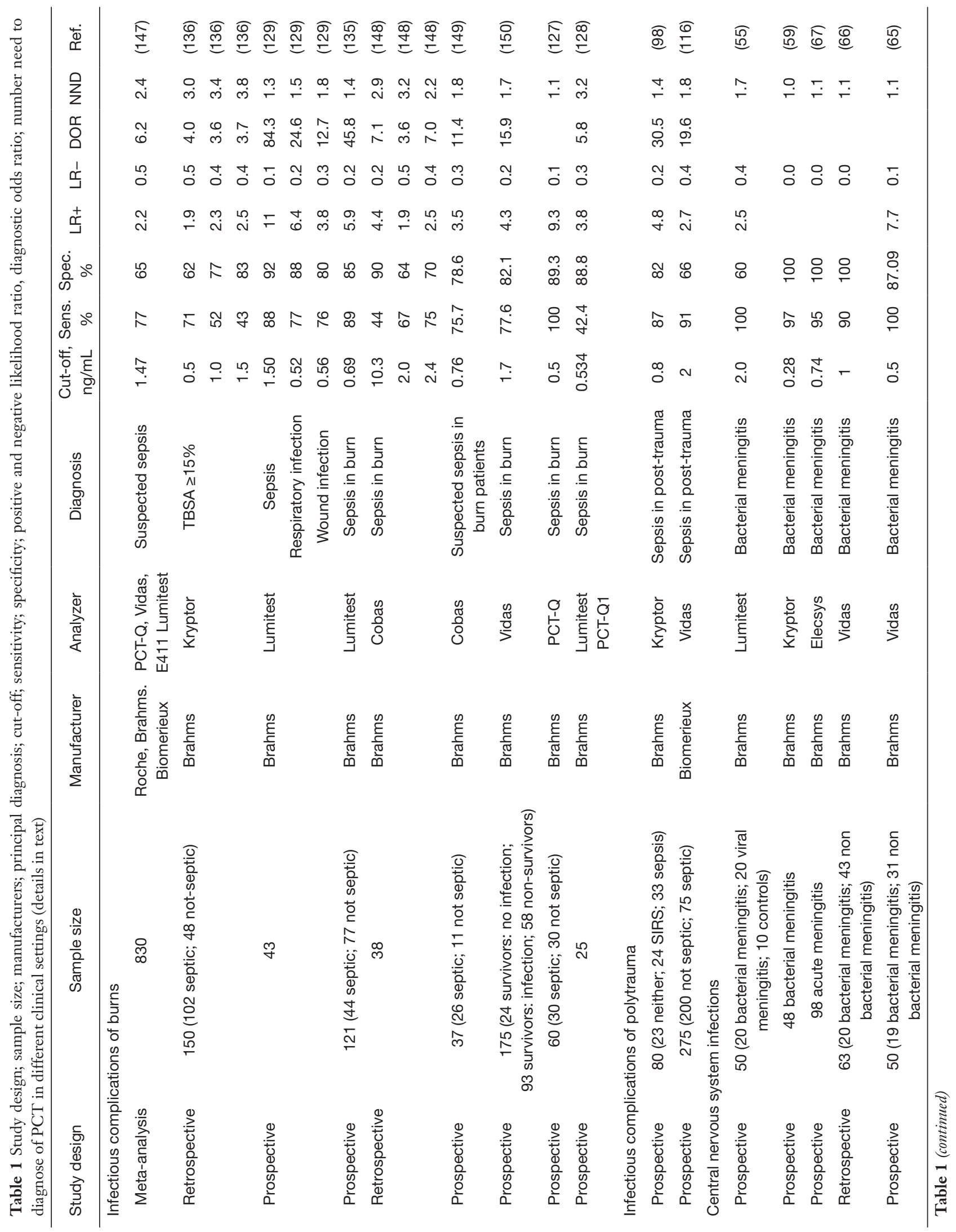




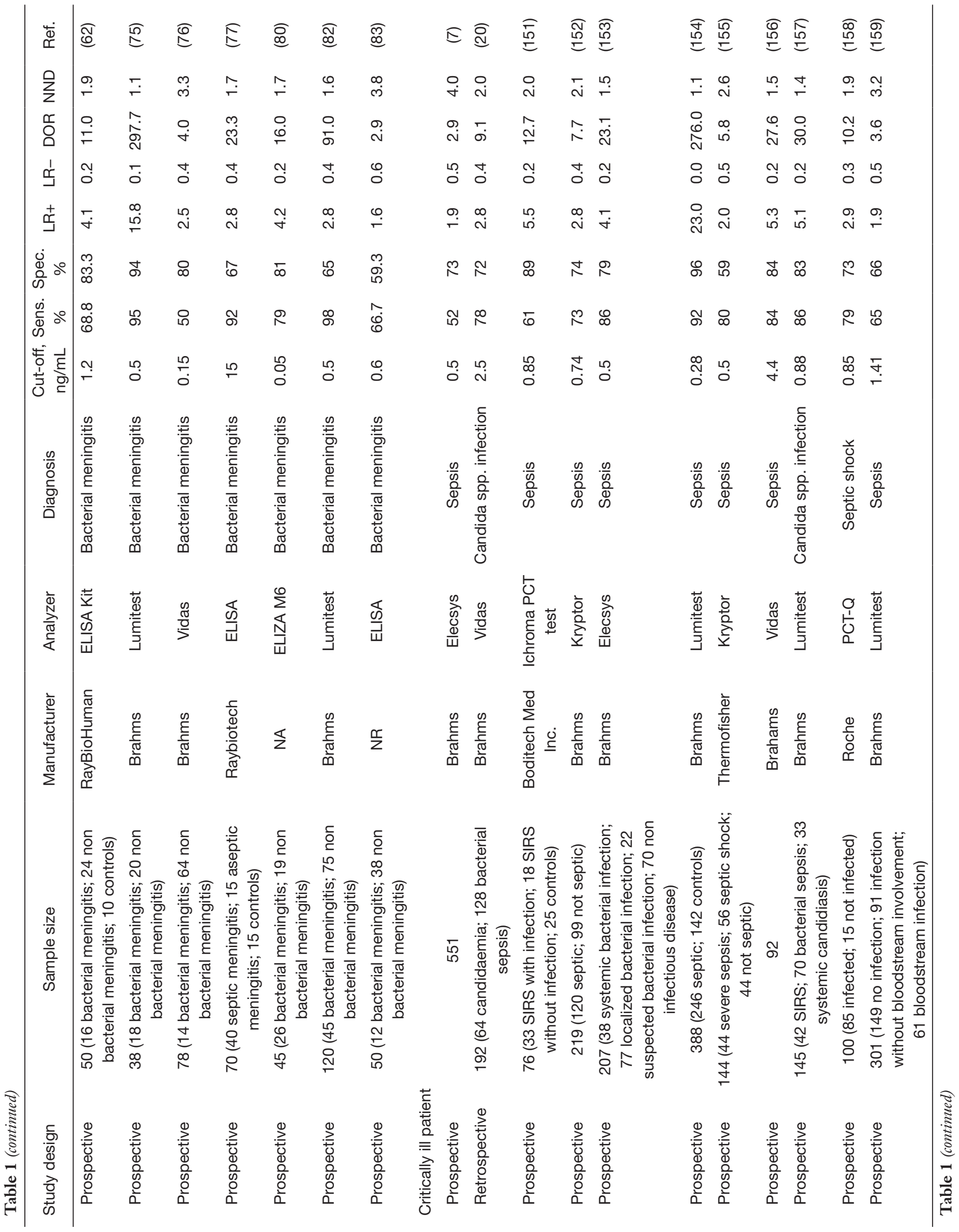




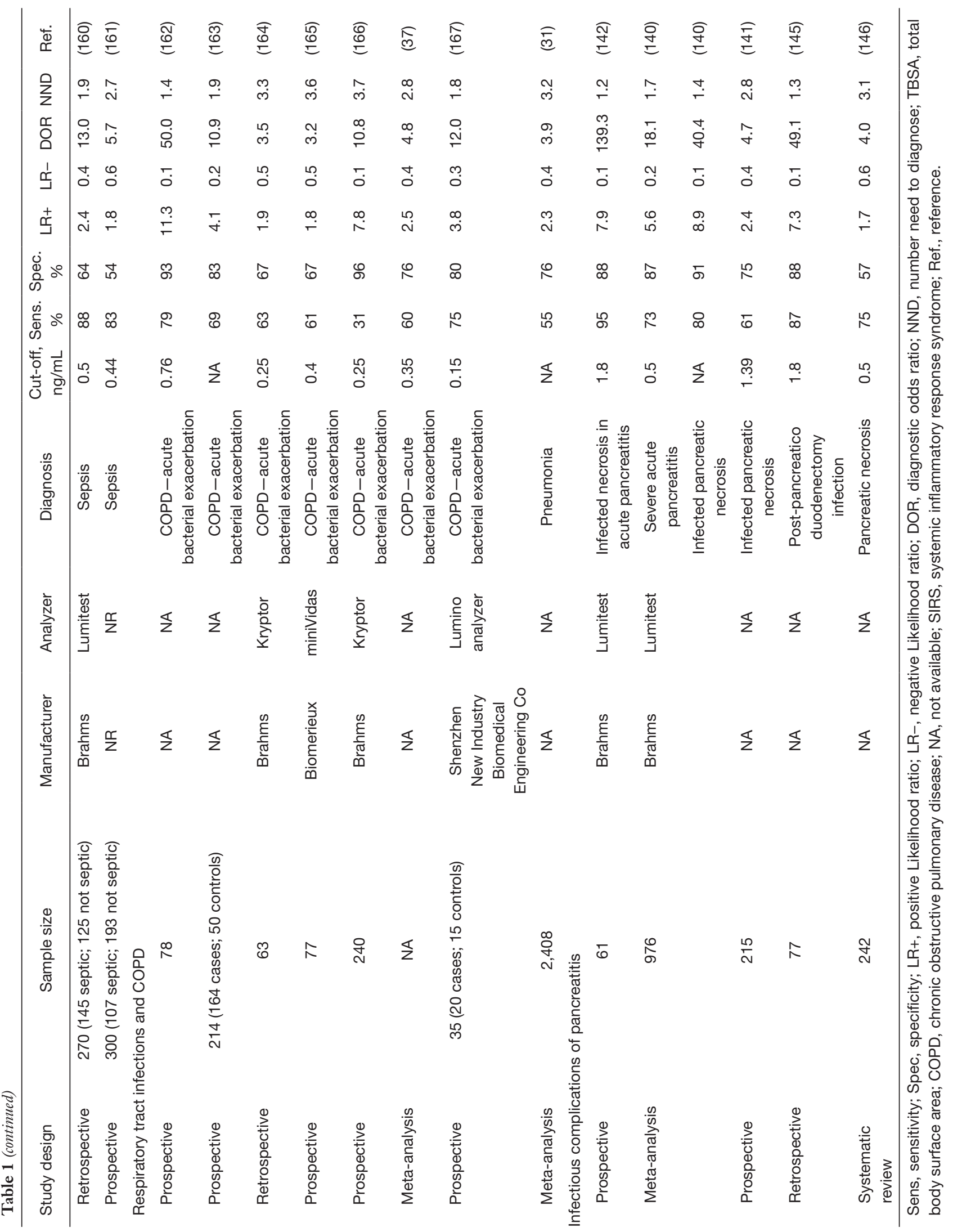




\section{Acknowledgments}

Funding: None.

\section{Footnote}

Provenance and Peer Review: This article was commissioned by the Guest Editors (Zhi-De Hu, Bing Gu) for the series "Advances in Laboratory Tests for Infectious Diseases" published in Annals of Translational Medicine. The article was sent for external peer review organized by the Guest Editors and the editorial office.

Conflicts of Interest: All authors have completed the ICMJE uniform disclosure form (available at http://dx.doi. org/10.21037/atm-20-1855). The series "Advances in Laboratory Tests for Infectious Diseases" was commissioned by the editorial office without any funding or sponsorship. The authors have no other conflicts of interest to declare.

Ethical Statement: The authors are accountable for all aspects of the work in ensuring that questions related to the accuracy or integrity of any part of the work are appropriately investigated and resolved.

Open Access Statement: This is an Open Access article distributed in accordance with the Creative Commons Attribution-NonCommercial-NoDerivs 4.0 International License (CC BY-NC-ND 4.0), which permits the noncommercial replication and distribution of the article with the strict proviso that no changes or edits are made and the original work is properly cited (including links to both the formal publication through the relevant DOI and the license). See: https://creativecommons.org/licenses/by-nc-nd/4.0/.

\section{References}

1. Schuetz P, Balk R, Briel M, et al. Economic evaluation of procalcitonin guided antibiotic therapy in acute respiratory infections: a US health system perspective. Clin Chem Lab Med 2015;53:583-92.

2. Dorizzi RM, Senna G, Caputo M. Likelihood ratios and Fagan's nomogram: valuable but underrated tools for in vitro latex sensitization assessment. Clin Chim Acta 1999;282:175-83.

3. Santuz P, Soffiati M, Dorizzi RM, et al. Procalcitonin for the diagnosis of early-onset neonatal sepsis: a multilevelprobabilistic approach. Clin Biochem
2008;41:1150-5.

4. Dorizzi RM, Polati E, Sette P, et al. Procalcitonin in the diagnosis of inflammation in intensive care units. Clin Biochem 2006;39:1138-43.

5. Kondo Y, Umemura Y, Hayashida K, et al. Diagnostic value of procalcitonin and presepsin for sepsis in critically ill adult patients: a systematic review and meta-analysis. J Intensive Care 2019;7:22.

6. Ugarte H, Silva E, Mercan D, et al. Procalcitonin used as a marker of infection in the intensive care unit. Crit Care Med 1999;27:498-504.

7. van der Does Y, Limper M, Jie KE, et al. Procalcitoninguided antibiotic therapy in patients with fever in a general emergency department population: a multicenter noninferiority randomized clinical trial (HiTEMP study). Clin Microbiol Infect 2018;24:1282-89.

8. Peng F, Chang W, Xie JF, et al. Ineffectiveness of procalcitonin-guided antibiotic therapy in severely critically ill patients: a meta-analysis. Int J Infect Dis 2019;85:158-66.

9. Jeon K, Suh JK, Jang EJ, et al. Procalcitonin-guided treatment on duration of antibiotic therapy and cost in septic patients (PRODA): a multi-center randomized controlled trial. J Korean Med Sci 2019;34:e110.

10. Shehabi Y, Sterba M, Garrett PM, et al. Procalcitonin algorithm in critically ill adults with undifferentiated infection or suspected sepsis. A randomized controlled trial. Am J Respir Crit Care Med 2014;190:1102-10.

11. Jensen JU, Hein L, Lundgren B, et al. Procalcitoninguided interventions against infections to increase early appropriate antibiotics and improve survival in the intensive care unit: a randomized trial. Crit Care Med 2011;39:2048-58.

12. Bouadma L, Luyt CE, Tubach F, et al. Use of procalcitonin to reduce patients' exposure to antibiotics in intensive care units (PRORATA trial): a multicenter randomized controlled trial. Lancet 2010;375:463-74.

13. Prkno A, Wacher C, Brunkorst FM, et al. Procalcitoninguided therapy in intensive care unit patients with severe sepsis and septic shock - a systematic review and metaanalysis. Crit Care 2013;17:R291.

14. Iankova I, Thompson-Leduc P, Kirson NY, et al. Efficacy and safety of procalcitonin guidance in patients with suspected or confirmed sepsis: a systematic review and meta-analysis. Crit Care Med 2018;46:691-8.

15. Hohn A, Schroeder S, Gehrt A, et al. Procalcitonin-guided algorithm to reduce length of antibiotic therapy in patients with severe sepsis and septic shock. BMC Infect Dis 
2013;13:158.

16. Wirz Y, Meier MA, Bouadma L, et al. Effect of procalcitonin-guided antibiotic treatment on clinical outcomes in intensive care unit patients with infection and sepsis patients: a patient-level meta-analysis of randomized trials. Crit Care 2018;22:191.

17. de Jong E, van Oers JA, Beishuizen A, et al. Efficacy and safety of procalcitonin guidance in reducing the duration of antibiotic treatment in critically ill patients: a randomized, controlled, open-label trial. Lancet Infect Dis 2016;16:819-27.

18. Bréchot N, Hekimian G, Chastre J, et al. Procalcitonin to guide antibiotic therapy in ICU. Int J Antimicrob Agents 2015;46:S19-24.

19. Albrich WC, Harbarth S. Pros and cons of using biomarkers versus clinical decisions in start and stop decisions for antibiotics in the critical care setting. Intensive Care Med 2015;41:1739-51.

20. Pieralli F, Corbo L, Torrigiani A, et al. Usefulness of procalcitonin in differentiating Candida and bacterial blood stream infections in critically ill septic patients outside the intensive care unit. Intern Emerg Med 2017;12:629-35.

21. Kelly BJ, Lautenbach E, Nachamkin I, et al. Combined biomarkers discriminate a low likelihood of bacterial infection among surgical intensive care patients with suspected sepsis. Diagn Microbiol Infect Dis 2016;85:109-15.

22. Oliveira CF, Botoni FA, Oliveira CRA, et al. Procalcitonin versus $\mathrm{C}$-reactive protein for guiding antibiotic therapy in sepsis: a randomized trial. Crit Care Med 2013;41:2336-43

23. Pepper DJ, Sun J, Rhee C, et al. Procalcitonin-guided antibiotic discontinuation and mortality in critically ill adults. Chest 2019;155:1109-18.

24. Kip MMA, Kusters R, Ijzerman MJ, et al. A PCT algorithm for discontinuation of antibiotic therapy is a cost-effective way to reduce antibiotic exposure in adult intensive care patients with sepsis. J Med Econ 2015;18:944-53.

25. Kip MMA, van Oers JA, Shajiei A, et al. Costeffectiveness of Procalcitonin Testing to Guide Antibiotic Treatment Duration in Critically Ill Patients: Results From a Randomised Controlled Multicentre Trial in the Netherlands. Crit Care 2018;22:293.

26. Schuetz P, Wirz Y, Sager R, et al. Procalcitonin to initiate or discontinue antibiotics in acute respiratory tract infections. Cochrane Database Syst Rev 2017;(10):CD007498.

27. Huang DT, Yealy DM, Filbin MR, et al. Procalcitonin- guided use of antibiotics for lower respiratory tract infection. N Engl J Med 2018;379:236-49.

28. Christ-Crain M, Stolz D, Bingisser R, et al. Procalcitonin guidance of antibiotic therapy in community-acquired pneumonia: a randomized trial. Am J Respir Crit Care Med 2006;174:84-93.

29. Briel M, Schuetz P, Mueller B, et al. Procalcitonin-guided antibiotic use vs a standard approach for acute respiratory tract infections in primary care. Arch Intern Med 2008;168:2000-7; discussion 2007-8.

30. Akagi T, Nagata N, Wakamatsu K, et al. Procalcitoninguided antibiotic discontinuation might shorten the duration of antibiotic treatment without increasing pneumonia recurrence. Am J Med Sci 2019;358:33-44.

31. Kamat IS, Ramachandran V, Eswaran H, et al.

Procalcitonin to distinguish viral from bacterial pneumonia: a systematic review and meta-analysis. Clin Infect Dis 2020;70:538-42.

32. Creamer AW, Kent AE, Albur M. Procalcitonin in respiratory disease: use as a biomarker for diagnosis and guiding antibiotic therapy. Breathe 2019;15:296-304.

33. Pantzaris ND, Spilioti DX, Psaromyalou A, et al. The use of serum procalcitonin as a diagnostic and prognostic biomarker in chronic obstructive pulmonary disease exacerbations: a literature review update. J Clin Med Res 2018;10:545-51.

34. Lin C, Pang Q. Meta analysis and systematic review of procalcitonin guided treatment in acute exacerbation of chronic obstructive pulmonary disease. Clin Respir J 2018;12:10-15.

35. Daubin C, Valette X, Thiollière F, et al. Procalcitonin algorithm to guide initial antibiotic therapy in acute exacerbations of COPD admitted to the ICU: a randomized multicenter study. Intensive Care Med 2018;44:428-37.

36. Chan HP, Lim TK. Procalcitonin and antibiotics in moderate-severe acute exacerbation of chronic obstructive pulmonary disease: to use or not to use - Curr Opin Pulm Med 2019;25:150-7.

37. Ni W, Bao J, Yang D, et al. Potential of serum procalcitonin in predicting bacterial exacerbation and guiding antibiotic administration in severe COPD exacerbations: a systematic review and meta-analysis. Infect Dis (Lond) 2019;51:639-50.

38. Verduri A, Luppi F, D'Amico R, et al. Antibiotic treatment of severe exacerbations of chronic obstructive pulmonary disease with procalcitonin: a randomized non inferiority trial. PLoS One 2015;10:e0118241. 
39. Mathioudakis AG, Chatzimavridou-Grigoriadou V, Corlateanu A, et al. Procalcitonin to guide antibiotic administration in COPD exacerbations: a meta-analysis. Eur Respir Rev 2017;26:160073.

40. Li Z, Yuan X, Yu L, et al. Procalcitonin-guided antibiotic therapy in acute exacerbation of chronic obstructive pulmonary disease. Medicine 2019; 98:e16775.

41. van der Maas ME, Mantjes G, Steuten LMG. Procalcitonin biomarker algorithm reduces antibiotic prescriptions, duration of therapy, and costs in chronic obstructive pulmonary disease: a comparison in the Netherlands, Germany, and the United Kingdom. OMICS 2017;21:232-43.

42. Schuetz P, Briel M, Mueller B. Clinical outcomes associated with procalcitonin algorithms to guide antibiotic therapy in respiratory tract infections. JAMA 2013;309:717-18.

43. Dixit D, Bridgeman MB, Andrews LB, et al. Acute exacerbations of chronic obstructive pulmonary disease: diagnosis, management, and prevention in critically ill patients. Pharmacotherapy 2015;35:631-48.

44. Wang J, Cao B. Procalcitonin and other markers to guide antibiotic use in chronic obstructive pulmonary disease exacerbations in the era of antimicrobial resistance. Curr Opin Pulm Med 2019;25:158-64.

45. Chang CH, Tsao KC, Hu HC, et al. Procalcitonin and C-reactive protein cannot differentiate bacterial or viral infection in COPD exacerbation requiring emergency department visits. Int J Chron Obstruct Pulmon Dis 2015;10:767-74.

46. Elmore JG, Horwitz RI, Quagliarello VJ. Acute meningitis with a negative Gram's stain: clinical and management outcomes in 171 episodes. Am J Med 1996;100:78-84.

47. Mekitarian Filho E, Horita SM, Gilio AE, et al. Cerebrospinal fluid lactate level as a diagnostic biomarker for bacterial meningitis in children. Int J Emerg Med 2014;7:14.

48. White K, Ostrowski K, Maloney S, et al. The utility of cerebrospinal fluid parameters in the early microbiological assessment of meningitis. Diagn Microbiol Infect Dis 2012;73:27-30.

49. Dubos F, Moulin F, Gajdos V, at al. Serum procalcitonin and other biologic markers to distinguish between bacterial and aseptic meningitis. J Pediatr 2006;149:72-6.

50. Peltola H, Jaakkola M. C-reactive protein in early detection of bacteremic versus viral infections in immunocompetent and compromised children. J Pediatr 1988;113:641-6.
51. Kono T, Otsuka M, Ito M, et al. Negative C-reactive protein in children with bacterial infection. Pediatr Int 1999;41:496-9.

52. Hofer N, Zacharias E, Muller W, et al. An update on the use of C-reactive protein in early-onset neonatal sepsis: current insights and new tasks. Neonatology 2012;102:25-36.

53. Hansson LO, Axelsson G, Linné T, et al. Serum C-reactive protein in the differential diagnosis of acute meningitis. Scand J Infect Dis 1993;25:625-30.

54. Wei TT, Hu ZD, Qin BD, et al. Diagnostic accuracy of procalcitonin in bacterial meningitis versus nonbacterial meningitis. A systematic review and meta-analysis. Medicine 2016;95:e3079.

55. Alkholi UM, Abd Al-Monem N, Abd El-Azim AA, et al. Serum procalcitonin in viral and bacterial meningitis. J Glob Infect Dis 2011;3:14-8.

56. Gendrel D, Raymond J, Assicot M, et al. Measurement of procalcitonin levels in children with bacterial or viral meningitis. Clin Infect Dis 1997;24:1240-2.

57. Prat C, Domínguez J, Rodrigo C, et al. Use of quantitative and semiquantitative procalcitonin measurement to identify children with sepsis and meningitis. Eur J Clin Microbiol Infect Dis 2004;23:136-8.

58. Dandona P, Nix D, Wilson MF, et al. Procalcitonin increase after endotoxin injection in normal subjects. J Clin Endocrinol Metab 1994;79:1605-8.

59. Viallon A, Guyomarc'h P, Guyomarc'h S, et al. Decrease of serum procalcitonin levels over time during treatment of acute bacterial meningitis. Crit Care 2005;9:R344-50.

60. Mills GD, Lala HM, Oehley MR, et al. Elevated procalcitonin as a diagnostic marker in meningiococcal disease. Eur J Clin Microbiol Infect Dis 2006;25:501.

61. Vikse J, Henry BM, Roy J, et al. The role of serum procalcitonin in the diagnosis of bacterial meningitis in adults: a systematic review and meta-analysis. Int J Infect Dis 2015;38:68-76.

62. Abdelkader NA, Mahmoud WA, Saber SM. Serum procalcitonin in Egyptian patients with acute meningitis and a negative direct cerebrospinal fluid examination. J Infect Public Health 2014;7:106-13.

63. Jereb M, Muzlovic I, Hojker S, et al. Predictive value of serum and cerebrospinal fluid procalcitonin levels for the diagnosis of bacterial meningitis. Infection 2001;29:209-12.

64. Knudsen TB, Larsen K, Kristiansen TB, et al. Diagnostic value of soluble CD163 serum levels in patients suspected of meningitis: comparison with CRP and procalcitonin. Scand J Infect Dis 2007;39:542-53.

65. Makoo ZB, Soltani HR, Hasani A, et al. Diagnostic 
value of serum and cerebrospinal fluid procalcitonin in differentiation bacterial from aseptic meningitis. Am J Infect Dis 2012;6:93-7.

66. O M, Seo DW, Kwak M, et al. Serum procalcitonin and C-reactive protein level as an early diagnostic marker of bacterial meningitis in the emergency department. Ann Emerg Med 2012;60:S22

67. Morales Casado MI, Moreno Alonso F, Juarez Belaunde AL, et al. Ability of procalcitonin to predict bacterial meningitis in the emergency department. Neurologia 2016;31:9-17.

68. Ray P, Badarouacossi G, Viallon A, et al. Accuracy of the cerebrospinal fluid results to differentiate bacterial from non bacterial meningitis, in case of negative Gram-stained smear. Am J Emerg Med 2007;25:179-84.

69. Schwarz S, Bertram M, Schwab S, et al. Serum procalcitonin levels in bacterial and abacterial meningitis. Crit Care Med 2000;28:1828-32.

70. Viallon A, Desseigne N, Marjollet O, et al. Meningitis in adult patients with a negative direct cerebrospinal fluid examination: value of cytochemical markers for differential diagnosis. Crit Care 2011;15:R136.

71. Viallon A, Zeni F, Lambert C, et al. High sensitivity and specificity of serum procalcitonin levels in adults with bacterial meningitis. Clin Infect Dis 1999;28:1313-16.

72. Dubos F, Korczowski B, Aygun DA, et al. Serum procalcitonin level and other biological markers to distinguish between bacterial and aseptic meningitis in children: a European multicenter case cohort study. Arch Pediatr Adolesc Med 2008;162:1157-63.

73. Onal H, Onal Z, Ozdil M, et al. A new parameter in the differential diagnosis of bacterial and viral meningitis. Neurosciences 2008;13:91-92.

74. Steinberg AV, Korzhenevich VI, Mihailova EV. Optimization of a diagnostic procedure for children with preliminary diagnosis of "meningitis". J Pediatr Infect Dis 2010;5:57-63.

75. Ibrahim KA, Abdel-Wahab AA, Ibrahim AS. Diagnostic value of serum procalcitonin levels in children with meningitis: a comparison with blood leukocyte count and C-reactive protein. J Pak Med Assoc 2011;61:346-51.

76. Choi SH, Choi SH. Predictive performance of serum procalcitonin for the diagnosis of bacterial meningitis after neurosurgery. Infect Chemother 2013;45:308-14.

77. Prasad R, Kapoor R, Mishra OP, et al. Serum procalcitonin in septic meningitis. Indian J Pediatr 2013;80:365-70.

78. Casado MI, Alonso FM, Pinedo BL, et al. Acute meningitis in the paediatric emergency department: diagnostic yield of procalcitonin and C-reactive protein. Pediatr Emerg Care 2014;30:849-50.

79. Konstantinidis T, Cassimos D, Gioka T, et al. Can procalcitonin in cerebrospinal fluid be a diagnostic tool for meningitis? J Clin Lab Anal 2015;29:169-74.

80. Umran RM, Radhi NH. Diagnostic value of serum procalcitonin level in differentiating bacterial from nonbacterial meningitis in children. Iran J Pediatr 2014;24:739-44.

81. Li Y, Zhang G, Ma R, et al. The diagnostic value of cerebrospinal fluid procalcitonin and lactate for the differential diagnosis of postneurosurgical bacterial meningitis and aseptic meningitis. Clin Biochem 2015;48:50-4.

82. Shen HY, Gao W, Cheng JJ, et al. Direct comparison of the diagnostic accuracy between blood and cerebrospinal fluid procalcitonin levels in patients with meningitis. Clin Biochem 2015;48:1079-82.

83. Sanaei Dashti A, Alizadeh S, Karimi A, et al. Diagnostic value of lactate, procalcitonin, ferritin, serum-C-reactive protein, and other biomarkers in bacterial and viral meningitis: A cross-sectional study. Medicine (Baltimore) 2017;96:e7637.

84. Rhee P, Joseph B, Pandit V, et al. Increasing trauma deaths in the United States. Ann Surg 2014;260:13-21.

85. Centers for Disease Control and Prevention, National Center for Injury Prevention and Control. Web-based Injury Statistics Query and Reporting System (WISQARS) [online] [2014] Available online: https://www.cdc.gov/ injury/wisquars/index.html

86. Steinwall D, Befrits F, Naidoo SR, et al. Deaths at a Level 1 Trauma Unit: a clinical finding and post-mortem correlation study. Injury 2012,43:91-5.

87. Baker CC, Oppenheimer L, Stephens B, et al. Epidemiology of trauma deaths. Am J Surg 1980;140:144-50.

88. Moore FA, Moore EE. Evolving concepts in the pathogenesis of post injury multiple organ failure. Surg Clin North Am 1995;75:257-77.

89. Tschoeke SK, Ertel W. Immunoparalysis after multiple trauma. Injury 2007;38:1346-57.

90. Bianchi ME. DAMPs, PAMPs and alarmins: all we needs to know about danger. J Leukoc Biol 2007;81:1-5.

91. Giannoudis PV. Current concepts of the inflammatory response after major trauma: an update. Injury 2003;34:397-404.

92. Pfeifer R, Tarkin IS, Rocos B, et al. Patterns of mortality and causes of death in polytrauma patients - has anything changed? Injury 2009;40:907-11. 
93. Pittet D, Rangel-Frausto S, Li N, et al. Systemic inflammatory response syndrome, sepsis, severe sepsis and septic shock: incidence, morbidities and outcomes in surgical ICU patients. Intensive Care Med 1995;21:302-9.

94. American College of Chest Physicians/Society of Critical Care Medicine Consensus Conference: definitions for sepsis and organ failure and guidelines for the use of innovative therapies in sepsis. Crit Care Med 1992;20:864-74.

95. Banada PP, Chakravorty S, Shah D, et al. Highly sensitive detection of Staphylococcus aureus directly from patient blood. PLoS One 2012;7:e31126.

96. Ciriello V, Gudipati S, Stavrou PZ, et al. Biomarkers predicting sepsis in polytrauma patients: current evidence. Injury 2013;44:1680-92.

97. AlRawahi AN, AlHinai FA, Doig CJ, et al. The prognostic value of serum procalcitonin measurements in critically injured patients: a systematic review. Critical Care. 2019;23:390-402.

98. Sakran JV, Michetti CP, Sheridan MJ, et al. The utility of procalcitonin in critically ill trauma patients. J Trauma Acute Care Surg 2012;73:413-8.

99. Balci C, Sivaci R, Akbulut G, et al. Procalcitonin levels as early marker in patients with multiple trauma under intensive care. J Int Med Res 2009;37:1709-17.

100. Castelli GP, Pognani C, Cita M, et al. Procalcitonin as a prognostic and diagnostic tool for septic complications after major trauma. Crit Care Med 2009;37:1845-9.

101. Castelli GP, Pognani C, Cita M, et al. Procalcitonin, C-reactive protein, white blood cells and SOFA score in ICU: diagnosis and monitoring of sepsis. Minerva Anestesiol 2006;72:69-80.

102. Meisner M, Adina H, Schmidt J. Correlation of procalcitonin and C-reactive protein to inflammation, complications, and outcome during the intensive care unit course of multiple-trauma patients. Crit Care 2006;10:R1.

103. Billeter A, Turina M, Seifert B, et al. Early serum procalcitonin, interleukin-6, and 24-hour lactate clearance: useful indicators of septic infections in severely traumatized patients. World J Surg 2009;33:558-66.

104. Keel M, Harter L, Reding T, et al. Pancreatic stone protein is highly increased during post-traumatic sepsis and activates neutrophil granulocytes. Crit Care Med 2009;37:1642-8.

105. Oberholzer A, Keel M, Zellweger R, et al. Incidence of septic complications and multiple organ failure in severely injured patients is sex specific. J Trauma 2000;48:932-7. 106. Wanner GA, Keel M, Steckholzer U, et al. Relationship between procalcitonin plasma levels and severity of injury, sepsis, organ failure, and mortality in injured patients. Crit Care Med 2000;28:950-7.

107.Egger G, Aigner R, Glasner A, et al. Blood polymorphonuclear leukocyte migration as a predictive marker for infections in severe trauma: comparison with various inflammation parameters. Intensive Care Med 2004;30:331-4.

108. Hensler T, Sauerland S, Lefering R, et al. The clinical value of procalcitonin and neopterin in predicting sepsis and organ failure after major trauma. Shock 2003;20:420-6.

109. Ren B, Zou G, Huang Y, et al. Serum levels of HSP70 and other DAMP proteins can aid in patient diagnosis after traumatic injury. Cell Stress Chaperones 2016;21:677-86.

110.Maier M, Wutzler S, Lehnert M, et al. Serum procalcitonin levels in patients with multiple injuries including visceral trauma. J Trauma 2009;66:243-9.

111.Andermahr J, Greb A, Hensler T, et al. Pneumonia in multiple injured patients: a prospective controlled trial on early prediction using clinical and immunological parameters. Inflamm Res 2002;51:265-72.

112. Mimoz O, Benoist JF, Edouard AR, et al. Procalcitonin and C-reactive protein during the early posttraumatic systemic inflammatory response syndrome. Intensive Care Med 1998;24:185-8.

113. Wojtaszek M, Sta kiewicz G, Torres K, et al. Changes of procalcitonin level in multiple trauma patients. Anaesthesiol Intensive Ther 2014;46:78-82.

114.Haasper C, Kalmbach M, Dikos GD, et al. Prognostic value of procalcitonin (PCT) and/or interleukin-6 (IL-6) plasma levels after multiple trauma for the development of multi organ dysfunction syndrome (MODS) or sepsis. Technol Health Care 2010;18:89-100.

115. Civil ID, Schwab CW. The Abbreviated Injury Scale, 1985 revision: a condensed chart for clinical use. J Trauma 1988;28:87-90.

116. Rajkumari N, Mathur P, Sharma S, et al. Procalcitonin as a predictor of sepsis and outcome in severe trauma patients: a prospective study. J Lab Physicians 2013;5:100-8.

117. Ertugrul BM, Yilmabasar A, Ertugrul O, et al. Do C-reactive protein and procalcitonin predict hospitalacquired infection in patients with trauma? Saudi Med J 2006;27:560-2.

118. Kramer G. Pathophysiology of burn shock and burn oedema. In: Total Burn Care (Herndon DN, 4th ed) 2012:103-13.

119.Pereira CT, Barrow RE, Sterns AM, et al. Age-dependent differences in survival after severe burns: a unicentric 
review of 1,674 patients and 179 autopsies over 15 Years. J Am Coll Surg 2006;202:536-48.

120.Krishnan P, Frew Q, Green A, et al. Cause of death and correlation with autopsy findings in burns patients. Burns 2013;39:583-8.

121. Greenhalgh DG. Sepsis in the burn patient: a different problem than sepsis in the generalpopulation. Burns Trauma 2017;5:23.

122. Greenhalgh DG, Saffle JR, Holmes JH, et al. American Burn Association consensus conference to define sepsis and infection in burns. J Burn Care Res 2007;28:776-90.

123. Simon L, Gauvin F, Amre DK, et al. Serum procalcitonin and C-reactive protein levels as markers of bacterial infection: a systematic review and meta-analysis. Clin Infect Dis 2004;39:206-17.

124.Mann EA, Wood GL, Wade CE. Use of procalcitonin for the detection of sepsis in the critically ill burn patient: A systematic review of the literature. Burns 2011;37:549-58.

125. Jones AE, Fiecktl JF, Brown MD, et al. Procalcitonin test in the diagnosis of bacteremia: a metaanalysis. Ann Emerg Med 2007;50:34-41.

126. Tang BM, Eslich GD, Craig JC, et al. Accuracy of procalcitonin for sepsis diagnosis in critically ill patients: systematic review and meta-analysis. Lancet Infect Dis 2007;7:210-7.

127. Barati M, Alinejad F, Bahar MA, et al. Comparison of WBC, ESR, CRP and PCT serum levels in septic and non-septic burn cases. Burns 2008;34:770-4.

128. Bargues L, Chancerelle Y, Catineau J, et al. Evaluation of serum procalcitonin concentration in the ICU following severe burn. Burns 2007;33:860-4.

129. Lavrentieva A, Kontakiotis T, Lazaridis L, et al. Inflammatory markers in patients with severe burn injury: what is the best indicator of sepsis? Burns 2007;33:189-94.

130.von Heimburg D, Steighorst W, Khorram-Sefat R, et al. Procalcitonin - a sepsis parameter in severe burn injuries. Burns 1998;24:745-50.

131. Neely AN, Fowler LA, Kagan RJ, et al. Procalcitonin in pediatric burn patients: an early indicator of sepsis? J Burn Care Rehabil 2004;25:76-80.

132. Sachse C, Machens HG, Felmerer G, et al. Procalcitonin as a marker for the early diagnosis of severe infection after thermal injury. J Burn Care Rehabil 1999;20:354-60.

133. Su L, Feng L, Zhang J, et al. Diagnostic value of dynamics serum sCD163, sTREM-1, PCT, and CRP in differentiating sepsis, severity assessment, and prognostic prediction. Mediators Inflamm 2013;2013:969875.

134.Zu H, Li Q, Huang P, et al. Therapeutic Value of blood purification and prognostic utilities of early serum procalcitonin, C Reactive Protein, and Brain Natriuretic Peptide levels in severely burned patients with sepsis. Cell Biochem Biophys 2015;72:259-63.

135. Mokline A, Garsallah L, Rahmani I, et al. Procalcitonin: a diagnostic and prognostic biomarker of sepsis in burned patients. Annals of Burns and Fire Disasters 2015;28:116-20.

136. Cabral L, Afreixo V, Santos F, et al. Procalcitonin for the early diagnosis of sepsis in burn patients: A retrospective study. Burns 2017;43:1427-34.

137.Stanojcic M, Vinaik R, Jeschke MG. Status and challenges of predicting and diagnosing sepsis in burn patients. Surgical Infections 2018;19:168-75.

138. Muñoz B, Suárez-Sánchez R, Hernández-Hernández O, et al. From traditional biochemical signals to molecular markers for detection of sepsis after burn injuries. Burns 2019;45:16-31.

139. Adachi T, Kishihara Y, Okano H, et al. The utility of procalcitonin for the patients with infected pancreatic necrosis and pancreatic abscess. Intensive Care Med Experimental 2015;33:a113.

140.Mofidi R, Suttie SA, Patil PV, et al. The value of procalcitonin at predicting the severity of acute pancreatitis and development of infected pancreatic necrosis: systematic review. Surgery 2009;146:72-81.

141.Chen HZ, Ji L, Li L, et al. Early prediction of infected pancreatic necrosis secondary to necrotizing pancreatitis. Medicine (Baltimore) 2017;96:e7487.

142. Rau B, Steinbach G, Baumgart K, et al. The clinical value of procalcitonin in the prediction of infected necrosis in acute pancreatitis. Intensive Care Med 2000;26:S159-64.

143.Leppäniemi A, Tolonen M, Tarasconi A, et al. 2019 WSES guidelines for the management of severe acute pancreatitis. World J Emerg Surg 2019;14:27.

144. Besselink M, van Santvoort H, Freeman M, et al. IAP/APA evidence-based guidelines for the management of acute pancreatitis. Pancreatology 2013;13:e1-15.

145. Iida H, Maehira H, Mori H, et al. Serum procalcitonin as a predictor of infectious complications after pancreaticoduodenectomy: review of the literature and our experience. Surg Today 2020;50;87-96.

146. Komolafe O, Pereira SP, Davidson BR, et al. Serum $\mathrm{C}$-reactive protein, procalcitonin, and lactate dehydrogenase for the diagnosis of pancreatic necrosis. Cochrane Database Syst Rev 2017;4:CD012645.

147. Cabral L, Afreixo V, Almeida L, et al. The use of Procalcitonin (PCT) for diagnosis of sepsis in burn patients: A meta-analysis. PLoS One 2016;11:e0168475. 
148.Xu Y, Jin X, Shao X, et al. Valuable prognostic indicators for severe burn sepsis with inhalation lesion: age. platelet count. and procalcitonin. Burns Trauma 2018;29;6:29.

149. Cakır Madenci Ö, Yakupoğlu S, Benzonana N, et al. Evaluation of soluble CD14 subtype (presepsin) in burn sepsis. Burns 2014;40:664-9.

150. Kim HS, Yang HT, Hur J, et al. Procalcitonin levels within 48 hours after burn injury as a prognostic factor. Ann Clin Lab Sci 2012;42:57-64.

151.Ali FT, Ali MA, Elnakeeb MM, et al. Presepsin is an early monitoring biomarker for predicting clinical outcome in patients with sepsis. Clin Chim Acta 2016;460:93-101.

152. Bauer PR, Kashyap R, League SC, et al. Diagnostic accuracy and clinical relevance of an inflammatory biomarker panel for sepsis in adult critically ill patients. Diagn Microbiol Infect Dis 2016;84:175-80.

153. Endo S, Suzuki Y, Takahashi G, et al. Usefulness of presepsin in the diagnosis of sepsis in a multicenter prospective study. J Infect Chemother 2012;18:891-97.

154. Enguix-Armada A, Escobar-Conesa R, García-De La Torre A, et al. Usefulness of several biomarkers in the management of septic patients: C-reactive protein. procalcitonin. presepsin and mid-regional proadrenomedullin. Clin Chem Lab Med 2016;54:163-8.

155. Klouche K, Cristol JP, Gilles V, et al. Diagnostic and prognostic value of soluble CD14 subtype (Presepsin) for sepsis and community-acquired pneumonia in ICU patients. Ann Intensive Care 2016;6:59.

156. Leli C, Ferranti M, Marrano U, et al. Diagnostic accuracy of presepsin (sCD14-ST) and procalcitonin for prediction of bacteraemia and bacterial DNAaemia in patients with suspected sepsis. J Med Microbiol 2016;65:713-9.

157. Miglietta F, Faneschi ML, Lobreglio G, et al. Procalcitonin. C-reactive protein and serum lactate dehydrogenase in the diagnosis of bacterial sepsis. SIRS and systemic candidiasis. Infez Med 2015;23:230-7.

158. Takahashi W, Nakada TA, Yazaki M, et al. Interleukin-6 Levels Act as a Diagnostic Marker for Infection and a Prognostic Marker in Patients with Organ Dysfunction in Intensive Care Units. Shock 2016;46:254-60.

159.van der Geest PJ, Mohseni M, Linssen J, et al. The intensive care infection score - a novel marker for the prediction of infection and its severity. Crit Care 2016;20:180.

160. Wong HR, Lindsell CJ, Lahni P, et al. Interleukin 27 as a sepsis diagnostic biomarker in critically ill adults. Shock 2013;40:382-6.

161. Yang Y, Xie J, Guo F, et al. Combination of C-reactive protein. procalcitonin and sepsis-related organ failure score for the diagnosis of sepsis in critical patients. Ann Intensive Care 2016;6:51.

162.Xiong G, Qiao B, Wu Z, et al. Diagnostic values of $\mathrm{C}$-reactive protein. procalcitonin and serum amyloid A in predicting bacterial infection in patients with acute exacerbations of chronic obstructive pulmonary disease. Int J Clin Exp Med 2018;11:7118-24.

163.Li Y, Xie L, Xin S, et al. Values of procalcitonin and $\mathrm{C}$-reactive proteins in the diagnosis and treatment of chronic obstructive pulmonary disease having concomitant bacterial infection. Pak J Med Sci 2017;33:566-9.

164.Ergan B, Sahin AA, Topeli A. Serum procalcitonin as a biomarker for the prediction of bacterial exacerbation and mortality in severe COPD exacerbations requiring mechanical ventilation. Respiration 2016;91:316-24.

165. Tanriverdi H, Ornek T, Erboy F, et al. Comparison of diagnostic values of procalcitonin. C-reactive protein and blood neutrophil/lymphocyte ratio levels in predicting bacterial infection in hospitalized patients with acute exacerbations of COPD. Wien Klin Wochenschr 2015;127:756-63.

166. Falsey AR, Becker KL, Swinburne AJ, et al. Utility of serum procalcitonin values in patients with acute exacerbations of chronic obstructive pulmonary disease: a cautionary note. Int J Chron Obstruct Pulmon Dis 2012;7:127-35.

167. Gao D, Chen X, Wu H, et al. The levels of serum procalcitonin and high-sensitivity C-reactive protein in the early diagnosis of chronic obstructive pulmonary disease during acute exacerbation. Exp Ther Med 2017;14:193-8.

168. Glas AS, Lijmer JG, Prins MH, et al. The diagnostic odds ratio: a single indicator of test performance. J Clin Epidemiol 2003;56:1129-35.

169. How good is that test II. Bandolier 27; 1996. Available online: http://www.jr2.ox.ac.uk/bandolier/painres/ download/Bando027.pdf

170.McGee S. Simplifying likelihood ratios. J Gen Intern Med 2002;17:646-9.

171. Grimes DA, Schulz KF. Refining clinical diagnosis with likelihood ratios. Lancet 2005;365:1500-5.

Cite this article as: Azzini AM, Dorizzi RM, Sette P, Vecchi M, Coledan I, Righi E, Tacconelli E. A 2020 review on the role of procalcitonin in different clinical settings: an update conducted with the tools of the Evidence Based Laboratory Medicine. Ann Transl Med 2020;8(9):610. doi: 10.21037/atm-20-1855 